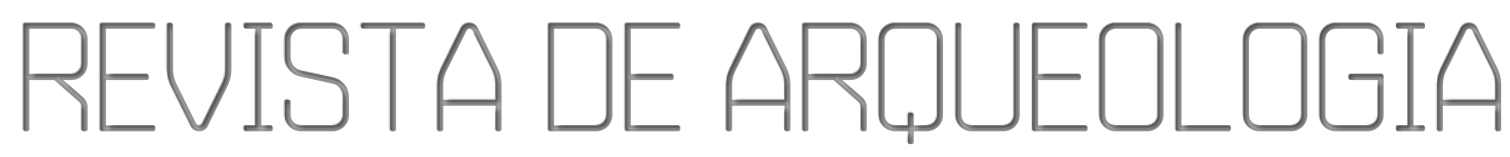

Volume 33 No. $3 \quad$ Setembro-Dezembro 2020

Edição Especial: Gestão de Acervos Arqueológicos

O PAPEL DOS ENDOSSOS NA MUSEALIZAÇÃO DA ARQUEOLOGIA:

INTERFACE PÚBLICO/PRIVADO NO MUSEU DE ARQUEOLOGIA E

PALEONTOLOGIA DE ARARAQUARA (MAPA)

Débora de Souza Simões*, Letícia Ribeiro Ferreira da Silva**,

Natália Carvalho de Oliveira Checchi ${ }^{\star \star *}$, Robson Rodrigues ${ }^{* \star \star *}$

RESUMO

Esse artigo tem por objetivo trazer a experiência do Museu de Arqueologia e Paleontologia de Araraquara (MAPA) em relação a emissão de endossos institucionais. Com isso, buscamos (i) trazer a trajetória do aparato legal que versa sobre o patrimônio arqueológico e sua proteção; (ii) apresentar as discussões sobre a Musealização da Arqueologia; e, então, (iii) descrever a experiência da gestão do acervo do MAPA realizada pela Prefeitura de Araraquara em parceria com a Fundação Araporã. A partir dessa experiência, conclui-se que essa gestão trouxe resultados positivos para o museu e deixou visível os benefícios da emissão de endosso, bem como a fragilidade do museu, pela falta de investimento em recursos humanos e materiais.

Palavras-chave: Musealização da Arqueologia; endosso institucional; Museu de Arqueologia e Paleontologia de Araraquara.

* Licenciada e Mestre em Ciências Sociais pela UNESP/Araraquara. Pesquisadora pela Fundação Araporã, Brasil. E-mail: debora-dss@hotmail.com. ORCID: http://orcid.org/0000-0002-0679-429X.

** Licenciada e bacharela em Ciências Sociais pela UNESP/Araraquara, Mestra em Arqueologia pelo MAE/USP. Pesquisadora pela Fundação Araporã, Brasil. E-mail: lekarib@hotmail.com.

ORCID: http://orcid.org/0000-0001-5785-5059.

*** Licenciada, bacharela e Mestre em Ciências Sociais pela UNESP/Araraquara. Pesquisadora pela Fundação Araporã, Brasil. E-mail: natalia.carvalho.gea@gmail.com. ORCID: http://orcid.org/0000-0002-1649-4004.

**** Doutor em Arqueologia pelo MAE/USP. Pesquisador do Programa de Pós-Graduação em Ciências Sociais da UFU. Coordenador de projetos em Arqueologia da Fundação Araporã, Brasil. E-mail: robson_arqueo@yahoo.com.br. ORCID: http://orcid.org/0000-0003-2679-5414. 


\section{THE ROLE OF ENDORSEMENTS IN ARCHAEOLOGY:}

\section{PUBLIC / PRIVATE INTERFACE IN THE MUSEUM OF ARCHAEOLOGY AND PALEONTOLOGY OF ARARAQUARA (MAPA]}

\section{ABSTRACT}

This article aims to bring the experience of the Museum of Archaeology and Paleontology of Araraquara (MAPA) concerning the issue of institutional endorsements. Thus, we seek to (i) bring the trajectory of the legal apparatus that deals with archaeological heritage and its protection; (ii) present the discussions on the Musealization of Archaeology; and then (iii) describe the experience of managing the MAPA collection carried out by the municipal administration in partnership with the Araporã Foundation. Thus, it is concluded that this management brought positive results to the museum and made visible the benefits of issuing an endorsement, as well as the fragility of the museum, due to the lack of investment in human and material resources.

Keywords: Musealization of Archaeology; institutional endorsement; Museum of Archaeology and Paleontology of Araraquara.

\section{EL PAPEL DE LOS ENDOSOS EN LA MUSEALIZACIÓN DE LA ARQUEOLOGÍA:}

\section{INTERFAZ PÚBLICO/PRIVADO EN EL MUSEO DE ARQUEOLOGÍA Y}

\section{PALEONTOLOGÍA DE ARARAQUARA (MAPA)}

\section{RESUMEN}

Este artículo tiene como objetivo acercar la experiencia del Museo de Arqueología y Paleontología de Araraquara (MAPA) sobre el tema de los endosos institucionales. Con ello, buscamos (i) acercar la trayectoria del aparato legal que se ocupa del patrimonio arqueológico y su protección; (ii) presentar las discusiones sobre la Musealización de la Arqueología; y luego (iii) describir la experiencia de manejo de la colección del MAPA realizada por la Municipalidad de Araraquara en alianza con la Fundación Araporã. De esta experiencia se concluye que esta gestión trajo resultados positivos al museo y hizo visibles los beneficios de emitir un endoso, así como la fragilidad del museo, debido a la falta de inversión en recursos humanos y materiales.

Palabras clave: Musealización de la Arqueología; endoso institucional; Museo de Arqueología y Paleontología de Araraquara. 


\section{INTRODUÇÃO}

O Museu de Arqueologia e Paleontologia de Araraquara (MAPA) é um museu municipal, situado no município de Araraquara, região central do estado de São Paulo. Foi inaugurado no ano de 2008, porém sua lei de criação ${ }^{1}$ data o ano de 2011 e foi marcada pela inauguração da exposição de longa duração do setor da Arqueologia, intitulada "Mapa: múltiplos olhares". Desde sua abertura ao público, o MAPA vem se consolidando enquanto instituição de referência na salvaguarda e comunicação do patrimônio arqueológico e paleontológico do interior paulista, adotando um modelo de museu de ciências que comporta Arqueologia e Paleontologia como campos do conhecimento integrados pelo campo da Museologia.

Enquanto uma instituição museológica que produz interpretações e discursos (CHAGAS, 2003), o MAPA definiu seu marco temático e trabalha com ele desde então, sendo o material icnofossilífero da Formação Botucatu para a área da paleontologia e a "construção de histórias indígenas para o interior paulista" no caso da Arqueologia (PLANO MUSEOLÓGICO DO MAPA, 2014, p. 28). Em consonância com a temática instituída, o Plano Museológico também estabeleceu o marco territorial do museu: no caso da Paleontologia, é a própria cidade de Araraquara e, para a Arqueologia, refere-se, para além da cidade de Araraquara, o interior paulista e a região conhecida como "Campos de Araraquara" - área delimitada pelos rios Tietê, Grande, Mogi-Guaçu e Paraná que, segundo Marcel Mano (2006, p. 21), não condizem com uma área geográfica ou culturalmente delimitada, mas sim, historicamente construída pelas entradas dos bandeirantes (séculos XVI e XVII) e das tropas militares (séculos XVIII e XIX), que ocorreram no seu entorno e não no seu interior.

A origem do MAPA remete ao processo de institucionalização da Arqueologia no município, iniciada em 1999; na ocasião, uma coleção de artefatos líticos arqueológicos sob salvaguarda do Museu Histórico e Pedagógico "Voluntários da Pátria" (MHPVP) correu risco de descarte. A partir desse ocorrido, um grupo formado por pesquisadores da Fundação Araporã se organizou e, como estratégia, passaram a inserir a discussão sobre os patrimônios junto ao poder público local e à comunidade em geral. Nesse mesmo período, o MHPVP foi credenciado e reconhecido junto ao Instituto do Patrimônio Histórico e Artístico Nacional (IPHAN) como instituição de salvaguarda legal do patrimônio arqueológico no município e, a partir de 2001, a instituição passou a fornecer apoio institucional a projetos ligados à Arqueologia preventiva desenvolvidos na região. Esse movimento somou-se a outra ação já existente, a qual contava com a atuação do paleontólogo araraquarense Marcelo Adorna Fernandes ${ }^{2}$, que, em parceria com a ONG Araraquara Viva, buscava a preservação e divulgação dos icnofósseis oriundos das pedreiras de arenito da cidade.

Este movimento de luta pelo reconhecimento do patrimônio no município de Araraquara culminou na criação de dois novos espaços: o MAPA e o Centro de Conservação e Restauração de Acervos Diversos (CECRAD), sendo este último dedicado à laboratório de recuperação, à triagem e à curadoria de acervos diversos. Além disso, na lei de criação ${ }^{3}$ do CECRAD ficou instituída a criação de uma reserva técnica para "abrigar os acervos provenientes de pesquisas arqueológicas a partir dos endossos de apoio

\footnotetext{
${ }^{1}$ Lei municipal n 7.575 de 28 de novembro de 2011. "Institui o MAPA - Museu de Arqueologia de Paleontologia de Araraquara e dá outras providências".

2 Professor titular da Universidade Federal de São Carlos, vinculado ao Programa de Pós Graduação em Ecologia e Recursos Naturais.

${ }^{3}$ Lei Municipal n 7732/12 de 24 de maio de 2012 "Institui o CECRAD - Centro de Conservação e Restauração de Acervos Diversos e dá outras providências".
} 
institucional fornecidos pelo MAPA - Museu de Arqueologia e Paleontologia de Araraquara e pelo Museu Histórico e Pedagógico "Voluntários da Pátria”. A verba para a concretização desses espaços veio por intermédio do Projeto "Parque dos Museus", enviado ao Ministério do Turismo junto à Caixa Econômica Federal.

Entre 2003 e 2020, o MAPA e o MHPVP juntos foram indicados em 180 portarias de pesquisa ${ }^{4}$, sendo que, a partir do ano de 2011, as portarias passaram a ser emitidas em nome do Museu de Arqueologia e Paleontologia de Araraquara, consolidando essa instituição no cenário paulista. Nesse sentido, a trajetória do MAPA está intrinsecamente conectada a do Museu Histórico.

Importante salientar que o MAPA não recebeu coleções/acervos arqueológicos em massa, uma vez que grande parte das portarias são provenientes de fases da pesquisa que geram pouco ou nenhum acervo, tais como: Diagnóstico, Prospecção, Avaliação de Impacto e Avaliação de Potencial de Impacto. Apenas 10 portarias fazem referência a resgates arqueológicos e isso demonstra uma prática consciente e responsável na emissão de endossos, já que a estrutura de salvaguarda do museu é limitada.

A Figura 1 apresenta o número de portarias de pesquisas no âmbito da arqueologia preventiva no estado de São Paulo. De acordo com Martinez (2006), as últimas duas décadas trazem uma nova configuração para a prática arqueológica realizada por profissionais não ligados às universidades, trazendo à baila também novas possibilidades de políticas de gestão do patrimônio. É nesse cenário, portanto, que a Musealização da Arqueologia nos pequenos museus do interior ganha força.

Figura 1 - Emissão de Portarias de Pesquisa pelo IPHAN no estado de São Paulo de 2003 até o presente. Gráfico feito pelos autores deste artigo a partir de dados cedidos por Zanettini Arqueologia (2020).

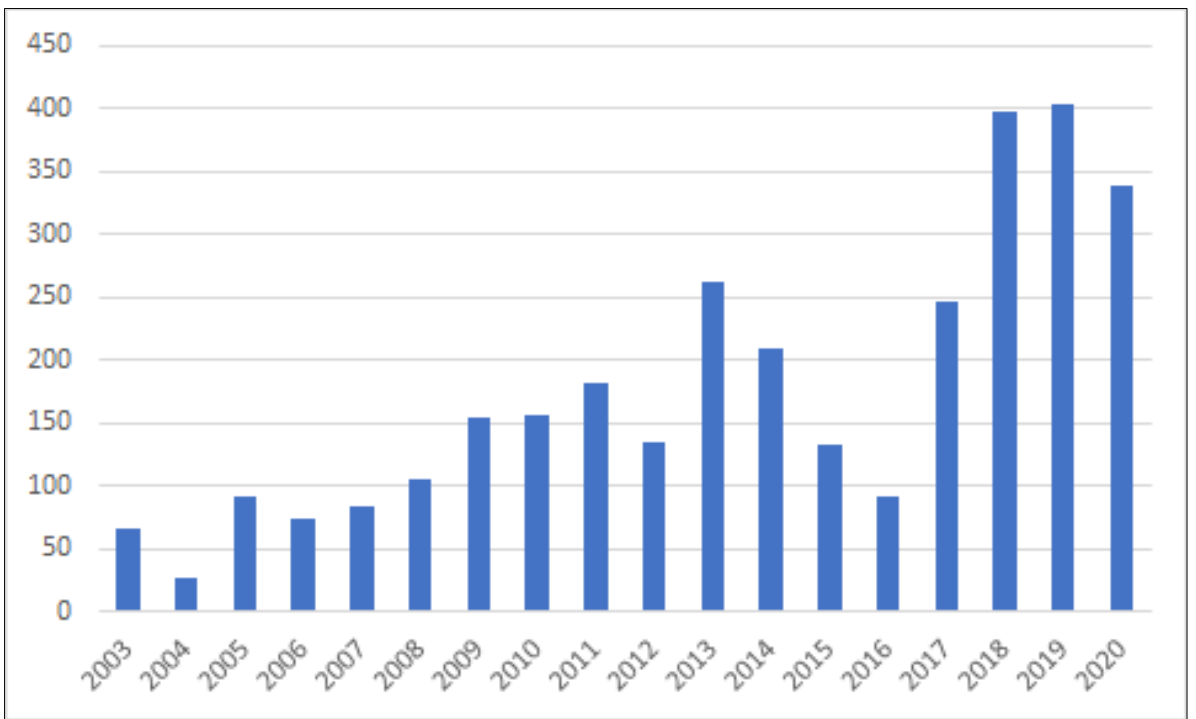

$\mathrm{O}$ apoio institucional às pesquisas arqueológicas tem sido uma constante na história do MAPA, acarretando ao mesmo tempo avanços e retrocessos na gestão do acervo salvaguardado. Diante do exposto, o presente artigo apresenta a experiência de uma parceria entre o setor público (Prefeitura Municipal de Araraquara) e o privado (Fundação Araporã) na gestão do MAPA, tendo como pano de fundo a Musealização da Arqueologia.

\footnotetext{
${ }^{4}$ Fontes: IPHAN e Zanettini Arqueologia (2020).
} 


\section{PATRIMÔNIO ARQUEOLÓGICO: ENDOSSO INSTITUCIONAL E A MUSEALIZAÇÃO DA ARQUEOLOGIA}

O termo patrimônio cultural, quando posto em pauta, pode desembocar em diferentes temas, como festas tradicionais, icnofósseis, parques, culinárias, danças, objetos, monumentos, entre tantos outros. Essa diversidade de categorias que sustenta e a infinidade de discussões que produz estão conectadas ao seu próprio conceito, ao seu constante alargamento e apropriação por diferentes segmentos da sociedade, seja no cotidiano, na educação, na ciência, seja na luta política.

A etimologia da palavra "patrimônio" refere-se a "pai" e "herança", uma herança que vem do pai, termo esse que, segundo o museólogo e poeta Mário Chagas, é passível de desconstrução. Lançando a ideia de herança que vem da mãe (matrimônio) e da "partilha social de bens culturais que se faz de modo sincrônico dentro de uma mesma época, de uma mesma geração (um fratrimônio)" (CHAGAS, 2003, p. 279), o conceito de patrimônio, quando ampliado à dimensão sociocultural, relaciona-se às histórias, memórias, lugares, objetos, identidades, saberes e a tudo que se deseja preservar, por estarem imbuídos de valor.

Nessa totalidade difusa que compreende o patrimônio (CHAGAS, 2003), seus diversos segmentos possuem histórias diferentes, tanto nas legislações quanto na sua prática. O patrimônio arqueológico aparece na legislação brasileira a partir do DecretoLei $n^{\circ}$ 25/1937, que constituiu o patrimônio histórico e artístico, sua preservação e tombamento. Nesse sentido, é possível afirmar que há um reconhecimento histórico dos bens arqueológicos enquanto patrimônios, ou seja, dotados de valores e de vontade de preservação; e isso ocorre porque os objetos arqueológicos estão diretamente conectados à história humana do passado, do presente e do futuro.

Após o Decreto-Lei de 1937, o patrimônio arqueológico retorna à legislação com o Código Penal de 1940, que prevê penalidade ao seu dano; e, nesse mesmo ano tem-se a criação do Registro de Sítios Arqueológicos. Funari e Robrahn-González (2008) ressaltam que a única lei federal destinada exclusivamente à proteção do patrimônio arqueológico é a Lei 3.924/61, aprovada pela luta do humanista Paulo Duarte pela preservação desse patrimônio, também reconhecido como o responsável pela implementação da Arqueologia Pública e acadêmica no Brasil.

É com essa lei que surgiram as primeiras garantias em relação ao acervo arqueológico gerado em campo, especificamente em seu artigo 16, parágrafo único, em que ficou determinado que as escavações arqueológicas ou pré-históricas fossem comunicadas, para fins de registro, à Diretoria do Patrimônio Histórico e Artístico Nacional, bem como apresentados os resultados obtidos e o destino do acervo.

Durante o período militar (1964-1985), a legislação e regulamentação sobre os assuntos do patrimônio arqueológico permaneceram praticamente estagnadas. Foi somente em 1981 que essas leis e regulamentações retornaram para o aparato legal brasileiro, sobretudo com a Política Nacional do Meio Ambiente em 1981; seguidas da Resolução do CONAMA em 1986; da Constituição Federal de 1988; e da Portaria SPHAN no 7 de 1988. É importante ressaltar que esta última colocou o IPHAN como órgão regulador da pesquisa arqueológica, definindo os procedimentos de salvamento e comunicação; e determinou a obrigatoriedade de "Declaração do endosso institucional" emitida pelas instituições científicas responsáveis pela salvaguarda do acervo arqueológico.

Em 2002, a Portaria IPHAN n 230 "normatizou a pesquisa arqueológica no âmbito de estudos de impacto e de licenciamento ambiental" (ZANETTINI; MORAES WICHERS, 2014, p. 241), trazendo a prerrogativa de uma responsabilidade mútua entre arqueólogos/as, instituições de guarda e empreendedores. Tal portaria instituiu ainda 
que a guarda dos acervos arqueológicos "deverá ser garantida pelo empreendedor, seja na modernização, na ampliação, no fortalecimento de unidades existentes, ou mesmo na construção de unidades museológicas específicas para o caso".

Por sua vez, a Instrução Normativa IPHAN no 001/2015 possibilitou a ampliação do leque de instituições responsáveis pela salvaguarda do acervo arqueológico proveniente da arqueologia preventiva, não se restringindo somente às "unidades museológicas”. Já a Portaria IPHAN 196/2016 criou o "Cadastro Nacional de Instituições de Guarda e Pesquisa” (CNIGP), o "Termo de Recebimento de Coleções Arqueológicas" e a "Ficha de Cadastro de Bem Arqueológico Móvel", trazendo à baila, com isso, requisitos mínimos a serem considerados na prática da conservação, documentação e comunicação do patrimônio arqueológico (LAIA, 2017).

\section{Musealização da arqueologia}

As discussões em torno da Musealização da Arqueologia elucidam a interface entre duas ciências: Arqueologia e Museologia. Diante disso, partimos das contribuições teóricas de Bruno (1999), Costa e Comerlato (2014) e Wichers (2014), que se debruçaram sobre a particularidade do patrimônio arqueológico nos museus.

A Musealização da Arqueologia proposta por Camila Moraes Wichers (2014) destrincha as funções de uma instituição museológica que salvaguarda o patrimônio arqueológico - ou seja, os processos de incorporação, salvaguarda, pesquisa e comunicação do acervo - utilizando as linhas teóricas das arqueologias pós processuais e da Sociomuseologia. A importância de trazer o debate que essa pensadora faz em relação ao tema em questão está no fato de que o MAPA fez parte de sua pesquisa de doutorado e, as ações posteriores ao seu trabalho ainda são influenciadas por tal debate, assunto que será tratado no tópico a seguir.

A dinâmica da Musealização da Arqueologia é esclarecida com a proposta de Cristina Bruno que consiste no estabelecimento de uma cadeia operatória que envolve esse processo, formada pelas funções do museu de Salvaguarda e Comunicação atreladas à realidade arqueológica, composta pelas referências patrimoniais, coleções e acervos. $\mathrm{Na}$ perspectiva de Wichers (2014, p. 25-26), a realidade arqueológica é composta por sítios arqueológicos, coleções do passado e coleções atuais, narrativas dos pesquisadores e narrativas da população local. A realidade arqueológica, contudo, é envolvida por um território patrimonial, pois o local onde o museu está inserido também fará parte desse processo, que é formado pela realidade sociocultural, por outras referências patrimoniais (materiais e imateriais) e pelos indicadores de memória. Em resumo, a instituição museológica deve conhecer seu acervo, suas narrativas e o território em que está inserido, para assim, aplicar suas metodologias de preservação e extroversão.

A função museológica de aquisição/coleta para os museus que salvaguardam o patrimônio arqueológico acontece em campo (WICHERS, 2014). No cenário contemporâneo da Arqueologia preventiva - em que a instituição museológica emite uma "Declaração de Endosso Institucional", ou seja, que garante o recebimento e salvaguarda de vestígios arqueológicos que ainda não foram escavados - pode-se ter como consequência a chegada desmedida de materiais às instituições, deixando elas e o patrimônio arqueológico em situação de fragilidade, por estarem despreparadas para assumir tais funções (COSTA; COMERLATO, 2014).

A falta de diálogo entre arqueólogos e instituições de guarda pode desembocar em mais uma forma de esquecimento da Arqueologia, das narrativas que produz e das memórias sociais atreladas às culturas materiais, fato esse que pode ser incorporado aos momentos históricos descritos por Cristina Bruno (1999) quando propõe a ideia de uma "estratigrafia do abandono". Segundo a autora, a Arqueologia brasileira sofreu processos 
históricos de desvalorização desde o período da colonização e, conectado a isso, estão o esquecimento e silenciamento de histórias e memórias dos povos nativos.

Nesse sentido, Costa e Comerlato (2014, p. 125-128) vislumbram possibilidades para amenizar ou mesmo reverter a situação de fragilidade das instituições museológicas e do patrimônio arqueológico. A primeira delas consiste em uma revisão legal em que colocaria as instituições de guarda enquanto ativas para a geração de acervo; a segunda propõe que o Instituto Brasileiro de Museus (IBRAM) também legisle para a proteção do patrimônio arqueológico; a terceira compreende uma negociação do arqueólogo com a instituição de guarda durante o processo de emissão da "Declaração de apoio institucional”, com a finalidade de garantir a preservação e extroversão do acervo quando já incorporado ao museu; e a quarta consiste na não emissão de endosso quando a instituição sentir que será prejudicada ou que ficará fragilizada.

\section{GESTÃO DO PATRIMÔNIO ARQUEOLÓGICO DO MAPA: A ATUAÇÃO DA FUNDAÇÃO ARAPORÃ}

Embora o MAPA seja um museu de tutela municipal, é por meio de profissionais vinculados à Fundação Araporã que esse museu nasceu e vem trilhando seu caminho no cenário amplo da musealização do patrimônio arqueológico.

Neste tópico, versaremos sobre o percurso da parceria entre a referida Fundação e a Prefeitura Municipal de Araraquara na última década, a partir do desenvolvimento de ações museológicas voltadas à salvaguarda e comunicação. Para tanto, nos embasamos no Plano Museológico do MAPA (2014), documento construído de forma coletiva a partir da parceria estabelecida entre Prefeitura Municipal de Araraquara, Fundação Araporã e Zanettini Arqueologia, com o objetivo de servir como ferramenta estratégica para ações futuras (MORAES WICHERS, 2011).

Ao dar início ao processo de construção do Plano Museológico, em 2010, identificou-se a necessidade de uma estrutura organizacional definida e de um planejamento museológico. Dessa feita, o documento construído prevê uma estrutura organizacional pautada em setores que desenvolvem ações específicas, conforme indicado na Figura 2.

Figura 2 - Estrutura organizacional do MAPA proposta no Plano Museológico (2014, p. 37).

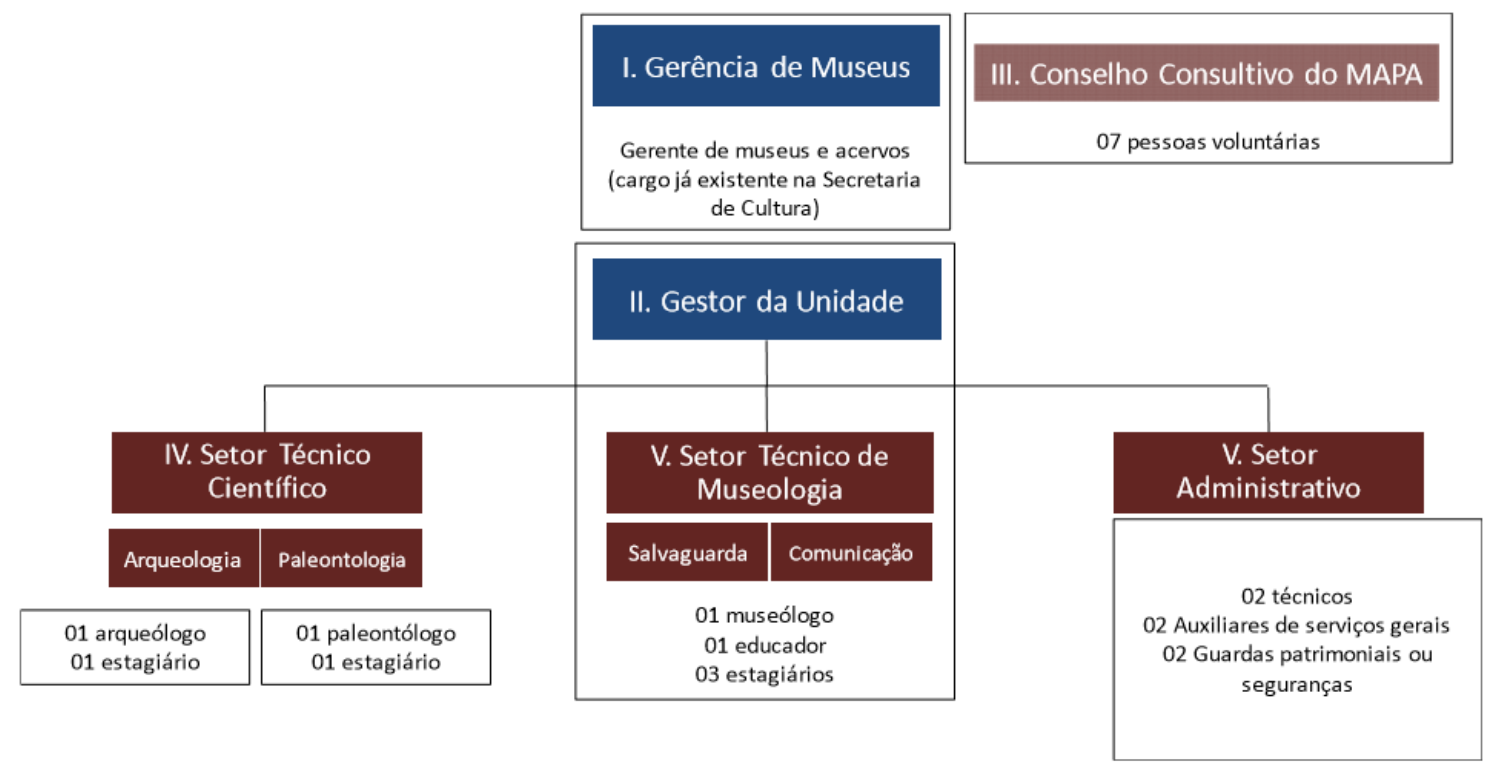


Em 2011, a parceria entre Fundação Araporã e Prefeitura Municipal de Araraquara foi formalizada por meio de um Convênio de Cooperação Técnica, Científica e Cultural, documento que prevê o desenvolvimento de pesquisas e ações culturais de arqueologia, museologia e patrimônio cultural e estabelece a função de cada instituição perante o museu. O convênio venceu em julho de 2016, porém as atividades desenvolvidas tiveram continuidade a partir de acordos estabelecidos entre a Gerência de Museus e a Fundação.

A função da Fundação no convênio era realizar pesquisas com o acervo; promover o encontro de professores da educação básica, de pesquisadores, graduandos e profissionais das áreas da Arqueologia, Paleontologia e Museologia com o museu; e propor projetos a serem desenvolvidos no MAPA. A Prefeitura Municipal ficou responsável por incentivar funcionários a trabalharem nos projetos propostos pela Fundação, pela zeladoria e manutenção predial.

Nessa empreitada, a Fundação junto com a Prefeitura Municipal formaram uma Comissão Gestora composta por um membro da Fundação e um membro da Prefeitura, sendo que essa mesma Comissão ficou responsável por nomear um/a coordenador/a de projeto, responsável por organizar as demandas do museu e estruturar os projetos a serem desenvolvidos na instituição.

$\mathrm{Na}$ prática, essa estrutura funcionou em partes, pois os projetos desenvolvidos foram propostos pela Fundação, bem como a escolha dos/as coordenadores/as dos projetos. Esses eram apresentados à Gerência de Museus que dava o aval para a sua execução. Nesse sentido, observa-se um protagonismo da Fundação em relação à Prefeitura, que se deu como consequência da falta de atuação da Prefeitura no museu. É importante ressaltar que os primeiros projetos estavam conectados ao trabalho desenvolvido por Camila Wichers no MAPA, ainda nesse momento de conhecimento da realidade arqueológica e de primeiras propostas educativas e, mais tarde, com a continuação do processo de curadoria.

Se a proposta do convênio era que duas instituições alcançassem juntas objetivos referentes ao museu, a realidade mostra que, na maior parte dos projetos, Prefeitura e Fundação atuaram separadas dentro do MAPA. Isso é possível de ser visualizado a partir da estrutura organizacional apresentada na Figura 3, que representa a realidade atual e que variou muito pouco desde a formalização do convênio.

Dentro do quadro apresentado, os funcionários administrativos contratados pela Prefeitura assumiram a responsabilidade da recepção do público escolar. Concomitantemente, a ausência de funcionários especializados (educadores, museólogos, conservadores, etc.) previstos no Plano Museológico e os constantes remanejamentos de funcionários no MAPA levaram a Fundação Araporã a dedicar seus esforços para suprir demandas básicas do Setor Técnico de Museologia, composto pelas áreas da Salvaguarda e Comunicação.

No convênio supracitado, ficou a cargo da Prefeitura e Fundação a responsabilidade pelas verbas a serem investidas nos projetos e, a partir de um acordo entre a Gerência de Museus do município de Araraquara e a Fundação Araporã, foi estabelecido que os recursos destinados seriam aqueles provenientes da emissão de apoio institucional.

A Fundação age como uma mediadora nesse processo de apoio institucional do MAPA, pois é ela que busca parceiros para o museu, assim como é dada a ela a responsabilidade pela negociação entre o empreendedor e o MAPA. Tal mediação pode ser caracterizada como a negociação proposta por Costa e Comerlato (2014) para amenizar as situações de fragilidade das instituições museológicas que emitem o endosso institucional. 
Figura 3 - Atual estrutura organizacional do MAPA definindo a atuação da Prefeitura e Fundação Araporã. Organograma produzido pelos autores para este artigo (2020).

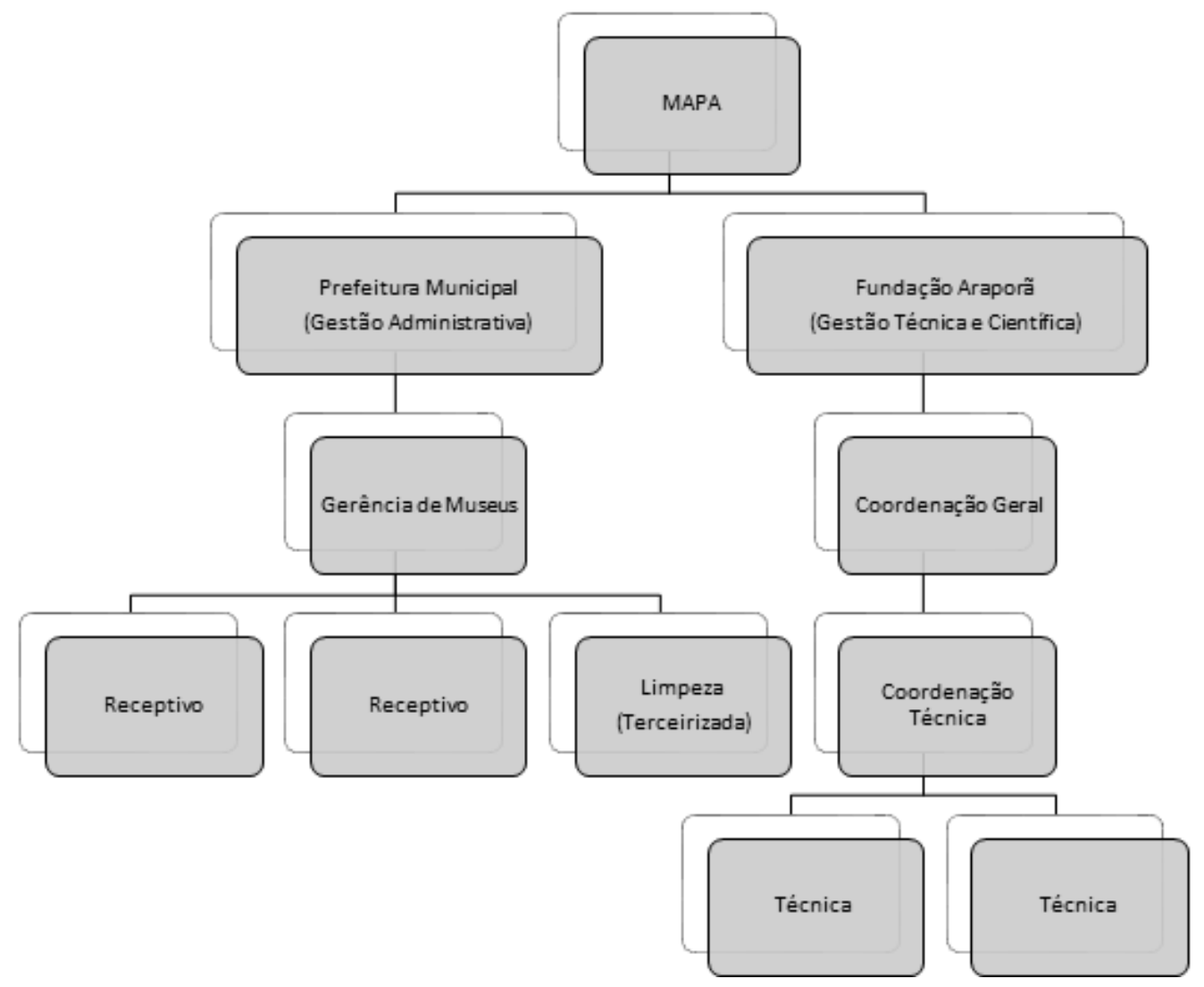

Como evidenciado na Introdução deste artigo, o MHPVP e MAPA foram indicados em 180 portarias, mas somente 10 em etapa de resgate arqueológico, mostrando uma responsabilidade com o acervo e uma noção das limitações estruturais do museu.

A contrapartida aos endossos é feita através de valores a serem revertidos em bens materiais ou o equivalente a $10 \%$ do valor do projeto de pesquisa arqueológica. Tais recursos foram aplicados na exposição de longa duração da Arqueologia e nos subsequentes Programas de Capacitação Técnica e Curadoria de Acervos Musealizados ${ }^{5}$, desenvolvidos anualmente pela Fundação Araporã, com objetivos específicos de modo a atender as necessidades de curadoria dos acervos do museu, voltadas à salvaguarda e comunicação. Vale salientar que, ao longo dos anos, a Fundação Araporã também concorreu em editais de fomento a projetos ligados à salvaguarda e comunicação do acervo arqueológico, colocando o MAPA como instituição beneficiada ${ }^{6}$.

Os Programas tiveram vigência nos anos de 2012, 2013, 2014, 2015, 2018, 2019 e resultaram em ações significativas no MAPA. Nos anos de 2016 e 2017, a Fundação Araporã não desenvolveu tais Programas por falta de recursos, dada a baixa emissão de endosso, momento condizente com a realidade do estado de São Paulo. Porém, a instituição não se desvinculou do museu, pois se responsabilizou por negociar os apoios institucionais, receber pesquisadores no museu e atualizar o inventário de acervo arqueológico e paleontológico. Importante salientar que este último foi realizado de

\footnotetext{
${ }^{5}$ A atuação da Fundação Araporã no MAPA se dá por meio de dois grupos de pesquisa: Grupos de Estudos Arqueológicos (GEA) e Grupo de Estudos em Museologia e Patrimônio (GEMP).

${ }^{6}$ No ano de 2020 a Fundação foi contemplada pelo edital do Programa de Ação Cultural (ProAC) na área de modernização de museus e pelo ProAC da Lei Aldir Blanc no edital de premiação por ação em museus, ambos os projetos serão desenvolvidos no MAPA no ano de 2021.
} 
forma colaborativa com estudantes de Biologia da Universidade de Araraquara (UNIARA), sob orientação da paleontóloga e museóloga Josiane Kunzler? .

Cabe apontar ainda que, a partir de 2018, essa mesma pesquisadora passou a integrar a equipe da Fundação Araporã como coordenadora responsável por desenvolver os trabalhos de capacitação técnica. A partir dessa coordenação, o leque de ações da Fundação no MAPA se expandiu para a área da Paleontologia e, na Museologia, retomou o Plano Museológico, propondo (e efetivando) a construção de documentos complementares a esse.

Apresentaremos nos tópicos a seguir algumas das atividades desenvolvidas pela equipe da Fundação Araporã, envolvendo ações de salvaguarda e comunicação do acervo arqueológico do MAPA e realizadas com os recursos dos apoios institucionais que o MAPA cedeu.

\section{Ações de salvaguarda}

Neste tópico buscaremos nos debruçar em algumas atividades voltadas à salvaguarda do acervo arqueológico do MAPA desde 2010 até o presente. Desde sua abertura em 2008, o museu já contava com acervo arqueológico bastante significativo (cerca de 50 mil peças de acordo com o diagnóstico das coleções realizado em 2010), porém a real situação das coleções, no que concerne ao número de peças e/ou sítios arqueológicos, ao estado de conservação, etc., era ainda desconhecida.

A primeira ação voltada à salvaguarda foi a realização de um diagnóstico das coleções, cujo objetivo era a avaliação preliminar do acervo "no que diz respeito ao seu estado de conservação e documentação, como também do seu potencial enquanto objeto de pesquisa e comunicação museológica” (PLANO MUSEOLÓGICO, 2014 p. 62). A ferramenta utilizada foi a Ficha de Cadastro de Coleção proposta por Moraes Wichers (2011, p. 309). Ou seja, foi o primeiro passo para se conhecer a realidade arqueológica da instituição (WICHERS, 2014).

No que se refere à documentação, o diagnóstico das coleções apontou que $20 \%$ delas não possuíam relatórios técnicos e $100 \%$ não contavam com documentação primária (perfis de escavação, croquis de campo, fichas de análise, entre outros) (PLANO MUSEOLÓGICO, 2014, p. 64). O resultado apresentado levou a equipe da Fundação Araporã a elaborar um Termo de Concessão de Endossos, o qual estabelece um conjunto de normas que devem ser cumpridas pelo empreendedor e arqueólogo responsável pelo projeto de pesquisa arqueológica, sendo o primeiro item do termo devotado ao material arqueológico e documentação produzida.

Além disso, a partir desse diagnóstico, foi elaborado o Inventário Geral de Acervo, documento que vem sendo periodicamente atualizado com dados dos acervos incorporados de 2014 em diante.

De acordo com o Inventário do MAPA (dados atualizados em 2019), o acervo arqueológico é composto atualmente por 91.274 peças $^{8}$, provenientes de 194 sítios arqueológicos, que representam 81 municípios, sendo 76, do interior paulista e cujos componentes mais recorrentes são artefatos cerâmicos e líticos. Apenas uma pequena parcela compreende evidências de outra natureza, tais como louças, vidros, metais e remanescentes ósseos humanos (ver Figura 4). Dessa feita, verificou-se que mais da metade do acervo do MAPA são testemunhos de ocupações de povos indígenas,

\footnotetext{
${ }^{7}$ Josiane Kunzler é bióloga, mestre em Geologia (na área de Paleontologia) e doutora em Museologia e Patrimônio pela Unirio.

${ }^{8}$ Parte significativa do acervo em questão encontra-se na reserva técnica, disponível para pesquisadores e pesquisadoras. Apenas 640 peças integram a exposição de longa duração "Mapa: múltiplos olhares".
} 
reconhecidos no contexto arqueológico como agricultores-ceramistas, característica que vai ao encontro do próprio marco temático do museu e das linhas de atuação da Fundação Araporã em relação às histórias e culturas indígenas.

Figura 4 - Acervo arqueológico por matéria prima. Gráfico produzido pelos autores deste artigo com base no Inventário Geral de acervos do MAPA (2020).

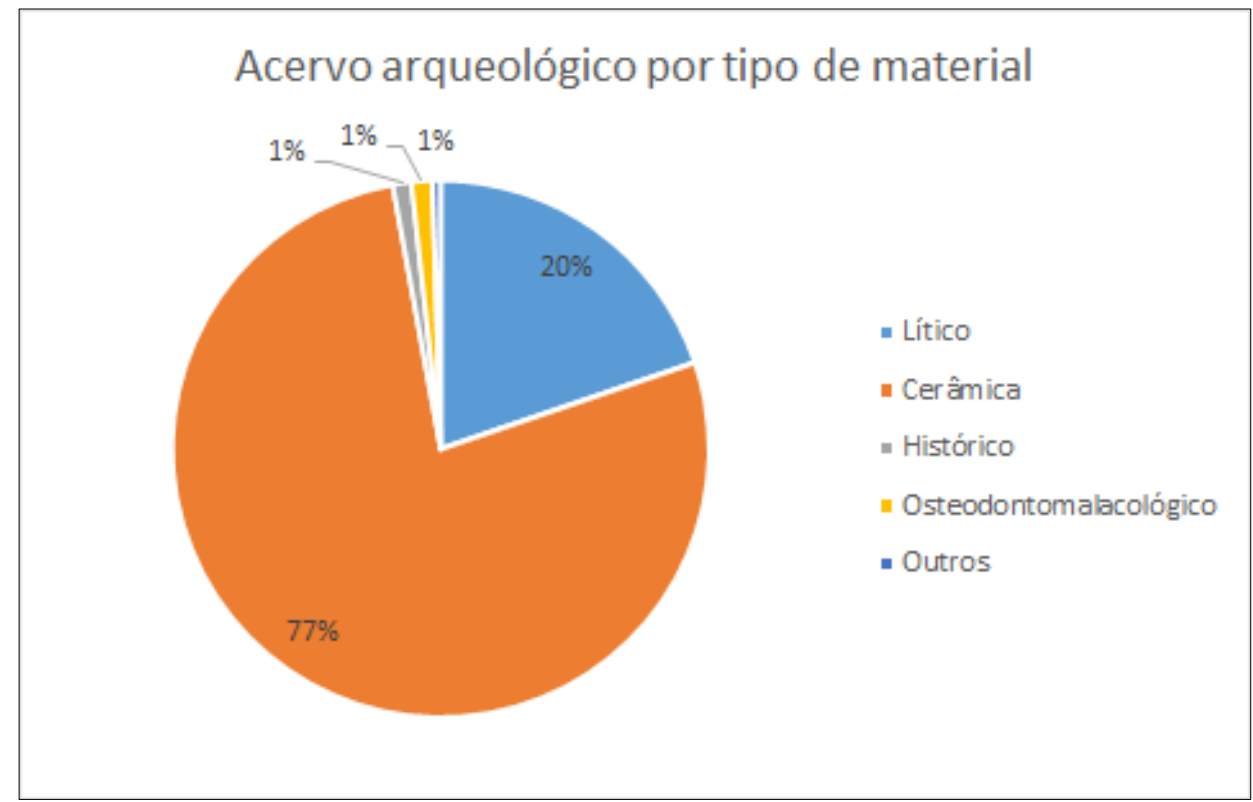

Gostaríamos de chamar atenção para o fato de que grande parte desse acervo (aproximadamente 89\%) resulta de pesquisas de Arqueologia preventiva: duas coleções (que somam sete sítios arqueológicos) são resultantes de pesquisas acadêmicas (RODRIGUES, 2007; SCHIAVETTO, 2007) e outras cinco coleções são provenientes de doações (ver Figura 5).

Figura 5 - Coleções arqueológicas de acordo com a forma de aquisição. Gráfico produzido pelos autores deste artigo com base no Inventário Geral de acervos do MAPA (2020).

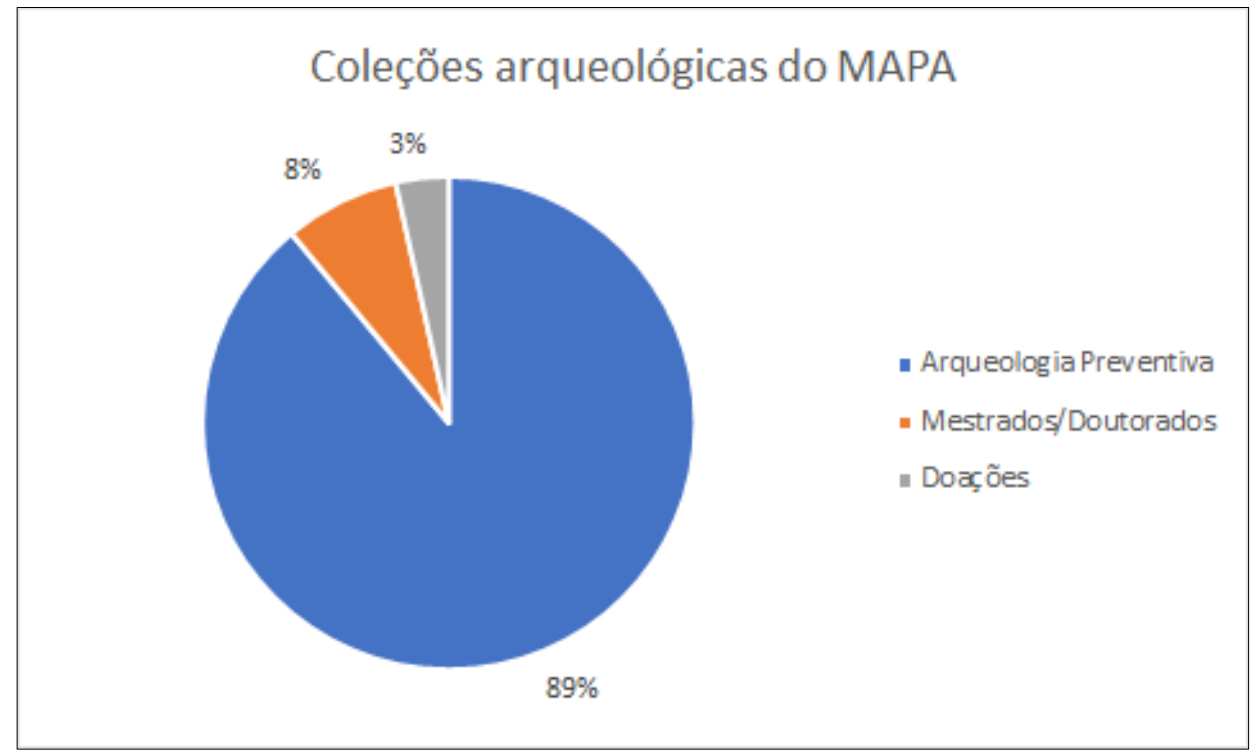


Os dados apresentados soam familiares para muitas instituições de guarda, uma vez que as pesquisas arqueológicas vinculadas às obras de engenharia e infraestrutura são responsáveis pela identificação de inúmeros sítios e pela geração de acervos de naturezas diversas, que, por sua vez, passam a incorporar coleções de museus em todo o país.

Ainda que a prática da arqueologia preventiva seja alvo de críticas diante das inúmeras limitações, tais como cronogramas apertados, verba limitada, segmentação da pesquisa, entre outros, ela é de suma importância para o conhecimento dos mais diversos contextos que afloram em todo o território nacional.

Outra atividade realizada com o acervo que merece destaque é a adequação do acondicionamento das coleções arqueológicas. Para tanto, foram realizadas duas ações simultâneas e associadas: a implantação de sistemas de controle e monitoramento ambiental e a padronização ${ }^{9}$ do acondicionamento das coleções de acordo com as características físicas da reserva técnica. Essas ações tiveram como objetivo adequar as áreas de reserva técnica para a conservação preventiva do acervo e também melhorar os sistemas de gerenciamento das coleções, colaborando para a implantação de um programa de curadoria permanente (FUNDAÇÃO ARAPORÃ, 2015). Além do espaço físico disponível para o acondicionamento, a equipe considerou características do próprio acervo, como matéria prima, peso e dimensões das peças, quantidade de peças por caixa, etc.

Figura 6 -Adequação no acondicionamento das coleções arqueológicas no MAPA, 2014. Fonte: Relatório Interno Programa de Capacitação Técnico Fundação Araporã (2015, p. 10).
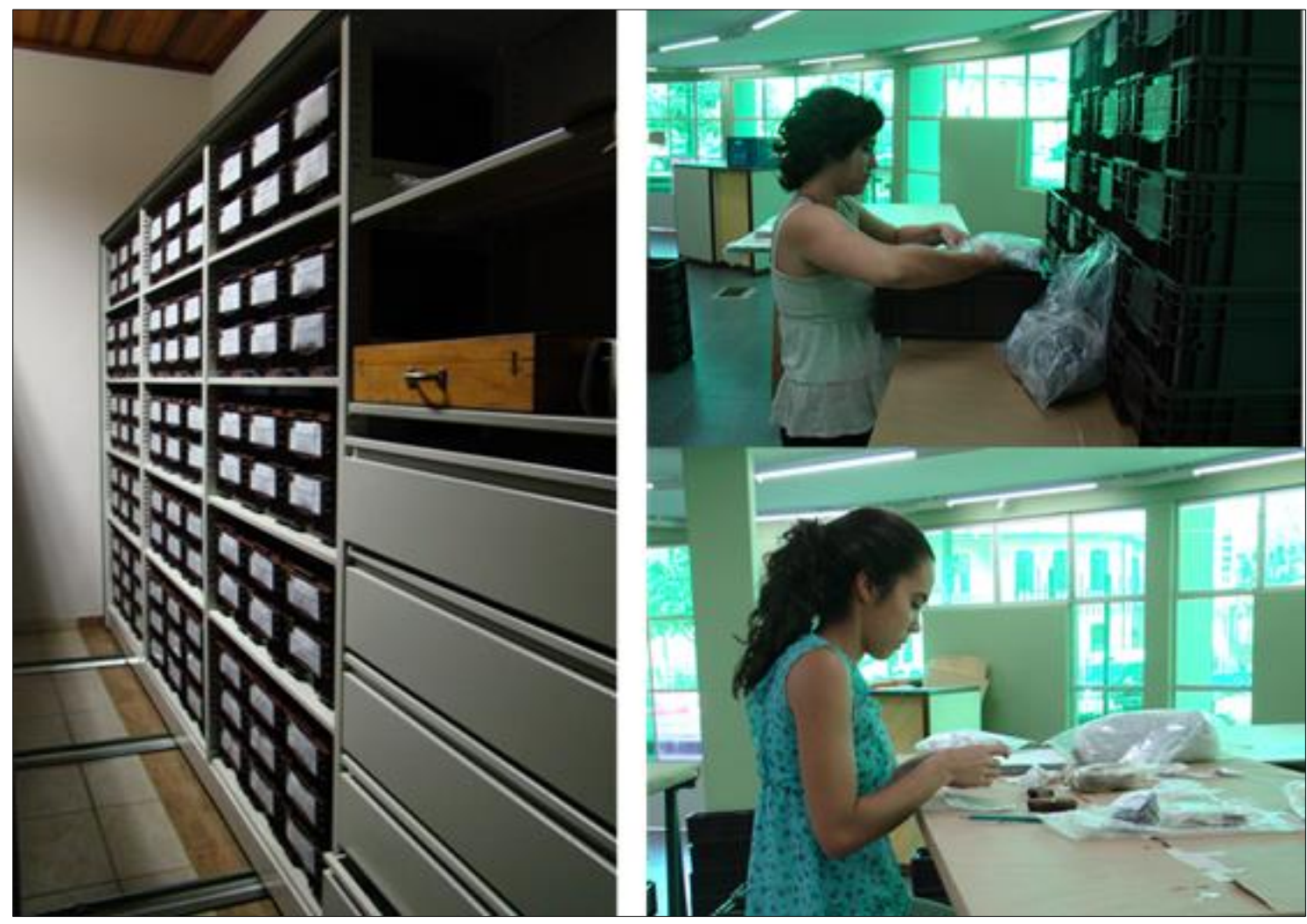

\footnotetext{
${ }^{9}$ A equipe técnica da Fundação Araporã elencou um modelo de caixa padrão que melhor se adequa ao armário disponível na reserva técnica. As especificações (material, cor e dimensões) da caixa modelo constam no Termo de Concessão de Endossos.
} 
Concomitantemente à adequação da reserva, a manipulação das coleções possibilitou duas atividades: a higienização do acervo que não havia recebido o devido tratamento e a formação de "coleções de referência", constituídas por peças "dotadas de 'apelo' museológico" (MORAES WICHERS, 2016 p. 47) e que poderão integrar futuras exposições de longa ou curta duração. Para além da seleção e formação das coleções de referência, em 2019, foram elaboradas diretrizes para a criação das coleções de referência a partir de um documento redigido de forma colaborativa com profissionais da arqueologia e da museologia.

Entre os anos de 2016 e 2017, o acervo do MAPA sofreu impactos causados pela negligência do poder público em relação aos museus da cidade. No caso específico do MAPA, a falta de manutenção e limpeza de calhas ocasionou a entrada de água de chuva nas dependências do museu, sendo a reserva técnica a mais afetada. Esse não é um problema do presente, a própria Fundação Araporã já realizou denúncias no Ministério Público para que a Prefeitura Municipal garantisse a preservação do prédio e do patrimônio presente no museu.

Diante da situação descrita, a Fundação Araporã realizou, no ano de 2018, um curso de Capacitação Teórico Prática em Museus com os funcionários do MAPA, do CECRAD e discentes do curso de Biologia da UNIARA. A capacitação buscou tornar familiar os assuntos do patrimônio e da Museologia, bem como discutir procedimentos que garantam a segurança do acervo. A partir das discussões oriundas dos encontros, foi construído um Plano de Gestão de Riscos para Acervos e o Termo de Recebimento de Bens. Nesse mesmo ano, foi elaborado o documento Procedimento Padrão de Incorporação de Acervo Arqueológico no MAPA, que descreve os procedimentos realizados atualmente quando um objeto ou um grupo de objetos se tornam acervo do museu. São eles: recebimento do material, conferência da documentação, conferência do material com a documentação e incorporação dos dados ao Inventário geral de acervos (FUNDAÇÃO ARAPORÃ, 2019).

Também foram implementadas ações de conservação curativa dos acervos. Essa medida é convocada quando o material sofre algum tipo de dano e necessita de reparação. No caso do MAPA, cerca de $1 \%$ do total do acervo arqueológico, número expressivo quando observamos o valor absoluto, foi impactado e desenvolveu bioinfestação decorrente da alta umidade. Os prejuízos poderiam ter sido maiores, mas devido às ações anteriores de acondicionamento apropriado (caixas de polietileno com tampa e sacos plásticos zipados), os danos foram amenizados.

No quesito da salvaguarda de acervos, a equipe da Fundação construiu uma estrutura de procedimentos a serem dados ao acervo do MAPA, como é o caso do processo de mediação para a emissão de apoio institucional, de incorporação do acervo, da padronização de guarda e das diretrizes para criação de coleções de referência. Porém, ressalta-se que ainda não se estruturou um documento de política de gestão do acervo, com a devida normatização de procedimentos de curadoria, gestão e documentação ${ }^{10}$.

\section{Ações de comunicação}

Entende-se por comunicação museal todas as atividades desenvolvidas no museu que envolvem diretamente o público, tendo por finalidade a comunicação e divulgação do acervo do museu. Desde 2010 a parceria com a Fundação Araporã possibilitou o desenvolvimento de ações significativas no campo dessa comunicação.

\footnotetext{
${ }^{10}$ A Fundação Araporã possui um projeto para a implementação de um Sistema de Informação e Documentação Museológica (SIDM) no MAPA, mas ainda não conseguiu executá-lo.
} 
A exposição é claramente uma das principais ferramentas de comunicação de um museu. No caso do MAPA, duas exposições ${ }^{11}$ temporárias antecederam a atual exposição de longa duração, ambas realizadas por uma equipe de técnicos da Fundação Araporã, porém sem o acompanhamento de um profissional da museologia. Nesse contexto, a exposição de longa duração "MAPA: Múltiplos Olhares" ${ }^{12}$, inaugurada em 2011, com curadoria de Camila Moraes Wichers, é considerada um marco no processo museológico dessa instituição.

A exposição MAPA: Múltiplos Olhares nasceu do processo de reestruturação do museu e das reflexões pertinentes ao diagnóstico museológico, entendido como fase prévia do plano museológico. Ficou evidente que uma das fragilidades do museu era a ausência de um discurso expositivo propriamente dito (MORAES WICHERS, 2011, p. 324).

Exposições de curta duração funcionam como estratégias importantes para inserção do museu na sociedade, pois consistem em um dos elementos que trazem dinamismo às instituições museológicas, chamando a atenção do público para as temáticas abordadas no museu. Além disso, são uma oportunidade para que o público tenha contato com acervos de outras instituições, bem como com acervos do MAPA que não compõem a exposição de longa duração.

Nesse sentido, a equipe da Fundação Araporã realizou cinco exposições de curta duração, listadas abaixo:

- “A Arqueologia vai à Escola” (2012), resultado de ações arqueológicas da Fundação Araporã voltadas à educação patrimonial;

- “Armadilhas Indígenas" (2014), resultado de um projeto de revitalização de valores tradicionais desenvolvidos pela E. E. "Índia Vanuíre" na terra indígena homônima. A exposição é composta por painéis com fotografias e textos elaborados por professores indígenas que contam os processos de manufatura de algumas armadilhas tradicionais dos povos Terena e Kaingang;

- "Expressões: o homem, a arte e o tempo" (2015), desenvolvida como extensão do mestrado da arqueóloga Luana Antoneto Alberto, devotada à musealização de sítios rupestres no estado de São Paulo;

- “Trajetórias de Aracoara: A história de Araraquara não começa com Pedro José Neto" (2016), realizada em parceria com o Grupo de Estudos de Educação Étnico Racial na Temática Indígena (GEERERI/Fundação Araporã) como resultado de um concurso de desenho lançado em comemoração aos 200 anos de Araraquara com o objetivo de questionar o apagamento da presença indígena na região;

- “Tecnologia lítica e os primeiros habitantes” (2018), realizada em parceria com a gerência de museus de Araraquara. Essa exposição teve como objetivo apresentar a temática sobre quem foram os primeiros habitantes do Brasil e da região, quando chegaram e como viviam, trazendo também o conhecimento sobre as técnicas utilizadas para a confecção dos instrumentos líticos.

\footnotetext{
${ }^{11}$ A primeira exposição foi montada em 2008 para a inauguração do MAPA e não recebeu um nome. A segunda, intitulada "Caçadores, Coletores e Horticultores da região de Araraquara" foi inaugurada em 2010 na reinauguração do museu após a elaboração de projetos para melhoria e execução das atividades do museu a serem submetidos ao Ministério da Cultura, Banco Nacional de Desenvolvimento Social (BNDES), Caixa Econômica Federal (CEF) e Emendas Parlamentares; editais do Instituto Brasileiro de Museus (PLANO MUSEOLÓGICO, 2014, p. 39).

12 A exposição "Mapa: múltiplos olhares" é o resultado de um processo coletivo de Musealização da arqueologia em Araraquara e, embora ela seja um marco significativo na história do museu, ela não é o foco deste artigo. Para quem se interessar em conhecer o processo de construção e os resultados obtidos, ambos são detalhados em Moraes Wichers (2011).
} 
Em paralelo às exposições, entre os anos de 2012 e 2013, a equipe da Fundação Araporã desenvolveu estratégias que permitiram realizar um diagnóstico preliminar do público do MAPA. A partir dos registros do livro de visitantes, da aplicação de Ficha de Perfil de Público direcionadas ao público espontâneo e de questionários de Avaliação de Multiplicadores destinados aos professores foi possível realizar reflexões sobre a inserção do MAPA na comunidade local.

O conjunto de estratégias supracitadas levou aos seguintes resultados: o público do MAPA é composto majoritariamente por grupos escolares de Araraquara e de municípios vizinhos, alcançando todas as fases da educação formal, desde o ensino infantil (o mais frequente) até o ensino médio. Com menor frequência, o museu recebeu grupos universitários e alunos da Educação de Jovens e Adultos (EJA). No que se refere ao público espontâneo, de acordo com as Fichas de Perfil de Público, aplicadas entre 2012 e 2013, 51\% dos visitantes são adultos jovens (entre 18 e 30 anos), ao passo que os idosos (pessoas com 60 anos ou mais) representam apenas $4 \%$ do público total.

Por ter um público escolar bastante expressivo, a equipe da Fundação Araporã, com o apoio da museóloga Camila Moraes Wichers, desenvolveu em 2012 roteiros de mediação com sugestões de temas e abordagens educativas específicas considerando os ciclos escolares (Ensino Infantil, Ensino Fundamental I, Ensino Fundamental II e Ensino Médio) tendo como base a exposição de longa duração "Mapa: múltiplos olhares". O objetivo foi criar um recurso didático que ficasse disponível para funcionários, estagiários e outros profissionais que pudessem ser incorporados ao quadro de funcionários do museu.

Outra ferramenta educativa foi a criação de kits didáticos, utilizados sobretudo em visitas de grupos escolares. O kit é composto por réplicas e/ou peças originais cuja procedência é desconhecida, com o objetivo de possibilitar experiências sensoriais aos alunos e professores.

Figura 7 - Atividades de comunicação: exibição de filme com temática arqueológica (2013) e montagem de exposição de curta duração (2015). Fonte: Arquivo da Fundação Araporã (2020).
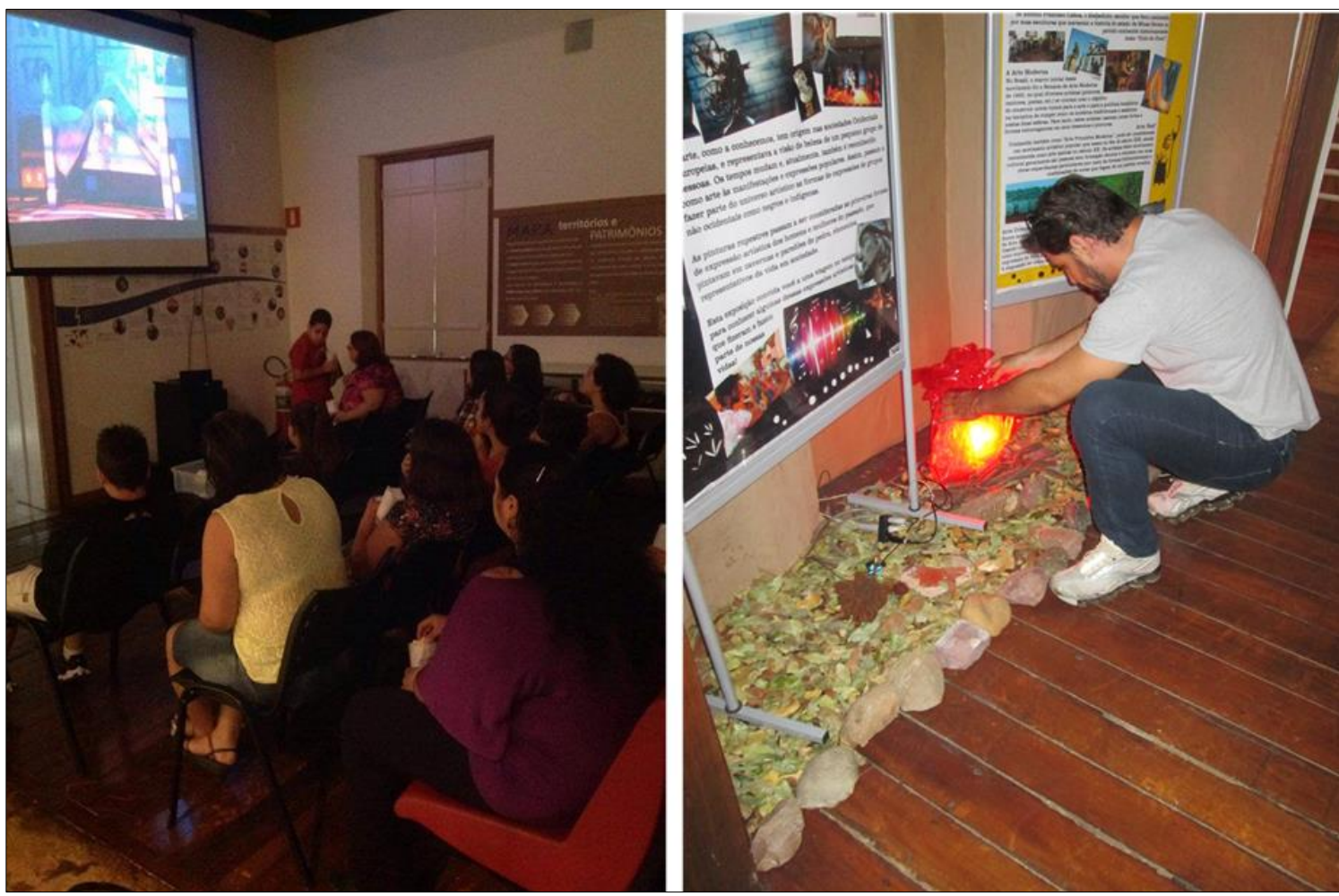


\section{CONSIDERAÇÕES FINAIS}

O presente artigo teve como objetivo refletir acerca da Musealização da Arqueologia, das problemáticas e possibilidades de gestão do acervo arqueológico a partir da Arqueologia preventiva, trazendo como exemplo a experiência da parceria estabelecida entre o setor público, representado pelo MAPA, e o setor privado, por meio da Fundação Araporã, a partir de um convênio técnico e científico acordado entre essas duas instituições.

As discussões teóricas abordadas trazem reflexões sobre o processo de Musealização da Arqueologia, bem como as problemáticas vividas pelas instituições que salvaguardam coleções arqueológicas oriundas de programas de gestão do patrimônio arqueológico ligado ao licenciamento ambiental, ou seja, a Arqueologia preventiva. Se o processo museológico de aquisição de acervo arqueológico se dá no campo (WICHERS, 2014), para as instituições que emitem o endosso, esse pode se tornar o primeiro problema a ser enfrentado pela instituição, pelo fato dela não participar do processo da etapa de campo e muitas vezes fornecer o apoio sem ter a noção das etapas das pesquisas arqueológicas e da quantidade de material que tais pesquisas podem gerar, como bem apontado por Costa e Comerlato (2014). No caso do MAPA, a partir de um acordo com a Gerência de Museus de Araraquara, a Fundação Araporã se tornou a principal responsável pela negociação e decisão de apoio ou não às pesquisas.

Tal decisão é tomada com base no marco temático e territorial definido no Plano Museológico do MAPA, bem como na fase em que a pesquisa arqueológica se encontra. Quando o aceite é dado e a declaração é emitida, o empreendedor e arqueólogo responsável tornam-se responsáveis por seguirem o "Termo de responsabilidade para concessão de endosso institucional”, que determina os critérios para a entrada do material no museu. Com isso, o museu consegue ter um maior controle sobre seu acervo.

Como evidenciado ao longo deste artigo, não somente o processo de aquisição de acervo, mas o trabalho em torno da Musealização da Arqueologia vivida pelo MAPA, em específico nas áreas de Salvaguarda e Comunicação, foi possível a partir dos Programas de Curadoria desenvolvidos pela Fundação Araporã e, tais programas aconteceram por causa dos apoios institucionais emitidos pelo MAPA. Ou seja, a partir de um convênio realizado com uma instituição que possui um corpo técnico que trabalha diretamente com a Arqueologia, o MAPA vem estruturando e consolidando sua gestão de acervos.

É possível realizar uma avaliação dessa parceria, bem como dos processos de musealização do patrimônio arqueológico a partir do Plano Museológico do MAPA, pois foi nesse documento que a Fundação se pautou para a realização de suas ações. Segundo o Plano Museológico (2014, p. 28), os objetivos do museu são:

- Ser um centro de excelência em pesquisas arqueológicas e paleontológicas;

- Promover um intercâmbio entre saberes 'científicos' e 'populares' para a construção de novos conhecimentos;

- A conservação, estudo, inventariação e divulgação do patrimônio existente na instituição, bem como a incorporação de bens arqueológicos e paleontológicos relevantes para a sociedade envolvente;

- Ampliar o diálogo com a sociedade, em especial, com segmentos em vulnerabilidade social;

- Realizar ações educativas de qualidade por meio de parcerias com a educação formal e não formal produção de materiais didáticos e formação de agentes multiplicadores.

Cremos que grande parte dos objetivos apontados no Plano Museológico foi atingido, sobretudo aqueles voltados à salvaguarda, comunicação museológica e ao reconhecimento da instituição como espaço de referência nas áreas de Arqueologia e Paleontologia - em especial no âmbito acadêmico, uma vez que o MAPA tem recebido 
pesquisadores que incluíram peças do acervo em suas pesquisas ${ }^{13}$. É possível afirmar que, a partir dos conceitos propostos por Wichers (2014), o MAPA conhece a sua realidade arqueológica, ou seja, os sítios, as coleções e as narrativas dos pesquisadores, mas ainda não alcançou as narrativas da população local.

Nesse sentido, ainda é necessário ampliar o diálogo com a sociedade envolvida e com os grupos em vulnerabilidade social. A esse respeito, a Fundação Araporã tem estabelecido um diálogo com lideranças do assentamento Bela Vista (localizado na zona rural de Araraquara) a fim de construir projetos devotados à preservação do patrimônio histórico e paleontológico local. No entanto, a efetivação da parceria ainda carece de recursos financeiros.

Os objetivos do museu estão em consonância com a visão de futuro da instituição, consolidada em 2014 e descrita no Plano Museológico a partir de ações a serem desenvolvidas em curto e médio prazos. Dentre as ações de curto prazo, as seguintes são apontadas no Plano Museológico (2014, p. 32):

- Produzir material educativo de apoio, aprimorando também os roteiros atuais;

- Oferecer uma programação cultural;

- Realizar a exposição de longa duração na Sala da Paleontologia;

- Ampliar pesquisas na área de Arqueologia, abrangendo outros segmentos, como por exemplo, Arqueologia Histórica.

Apenas dois dos tópicos supracitados foram alcançados: a realização de uma exposição de longa duração do setor da Paleontologia e a programação cultural, que abrangeu exposições de curta duração, exibições de filmes com temáticas arqueológicas, palestras, cursos, entre outros.

A visão de futuro a médio prazo prevista no Plano Museológico (2014, p. 32) é:

- Tornar-se uma instituição referência como museu especializado no contexto do interior paulista;

- Ampliar a visibilidade do MAPA nas comunidades de Araraquara, atuando de forma significativa com grupos em vulnerabilidade social e formando novos públicos;

- Fazer com que a imagem da cidade de Araraquara não possa ser divorciada da imagem do museu;

- Ter como parceiros sólidos instituições de ensino, pesquisa e extensão, empresas de arqueologia de SP, museus de SP e fundações;

- Colaborar de forma significativa no desenvolvimento local e regional;

- Criar mecanismos para autogestão do MAPA;

- Fazer da mediação do MAPA uma referência no Estado de São Paulo;

- Efetuar melhorias significativas nas instalações da reserva técnica e nos laboratórios do MAPA e CECRAD.

- Possuir instalações adaptadas e preparadas para receber públicos com necessidades especiais (idosos, deficientes, etc);

- Possuir um corpo de funcionários qualificado e mais envolvido com as ações educativas e com outras esferas de atuação do MAPA.

A parceria MAPA/Fundação Araporã tem colaborado com o processo de descentralização das ações de Musealização da Arqueologia (MORAES WICHERS, 2011), alçando o MAPA como instituição de referência em nível regional por meio do desenvolvimento de ações de comunicação e salvaguarda. No entanto, os objetivos restantes apontados na "visão de futuro" não foram alcançados. Com base nas

\footnotetext{
${ }^{13}$ A título de exemplo, citamos as análises realizadas por Mercedes Okumura e João Carlos Moreno de Sousa (SOUSA, 2019), que realizaram análises de exemplares de pontas de projétil, incorporando o acervo do MAPA.
} 
responsabilidades dos parceiros, enumeradas no Plano Museológico, apontamos o não cumprimento da Prefeitura em garantir recursos humanos (profissionais especializados, contratados para assumir funções específicas) para o desenvolvimento adequado de programas de comunicação e salvaguarda. Essa falta levou a Fundação Araporã a assumir atividades como mediação com grupos escolares (durante alguns anos), organização de exposições, documentação, conservação preventiva e curativa, entre outros. Dessa feita, os recursos advindos de endosso que poderiam ser investidos também no desenvolvimento de pesquisa e extensão, são aplicados em atividades básicas do museu.

É possível avaliar como positiva a gestão do acervo realizada pela Fundação até o momento, porém, a depender dos recursos oriundos dos apoios institucionais, não é viável, pois tais recursos não garantem as demandas de uma instituição museológica e, mesmo que a Fundação mantenha ações pontuais sem recursos de endosso ou busque outras formas de fomento, ela ainda não dará conta de gerir o MAPA. Nesse sentido, se o museu seguir negligenciado pelo poder público e continuar sem uma gestão permanente e, ainda pior, sem o básico de uma manutenção predial, o futuro da instituição torna-se incerto.

Essa assimetria e o consequente descaso do poder público diante do patrimônio arqueológico é mais um sintoma da política de apagamento da memória e da cultura dos povos indígenas do Brasil desde o período colonial (BRUNO, 1999). Nesse sentido, a atuação da Fundação Araporã e a escolha pelo marco temático do MAPA podem ser entendidos como uma ação militante de resistência dessas histórias. 


\section{REFERÊNCIAS BIBLIOGRÁFICAS}

ALBERTO, Luana Antoneto. Registros rupestres de São Paulo: conhecer para preservar. 2014. Dissertação (Mestrado em Arqueologia). MAE/USP, São Paulo, 2014.

BRUNO, Maria Cristina Oliveira. Musealização da arqueologia. Cadernos de Sociomuseologia, n 17. Lisboa, Universidade Lusófona de Humanidades e Tecnologias, 1999.

CHAGAS, Mário de Souza. Imaginação Museal: Museu, Memória e Poder em Gustavo Barroso, Gilberto Freyre e Darcy Ribeiro. 2003. Tese (Doutorado em Ciências Sociais), Universidade do Estado do Rio de Janeiro, Rio de Janeiro, 2003.

COSTA, Carlos Alberto Santos; COMERLATO, Fabiana. Você me daria um "cheque em branco"? Um olhar sobre o endosso institucional em projetos de arqueologia. Revista de Arqueologia, v. 26, n. 2/1, p. 115-131, 4 jul. 2014. Disponível em: https://doi.org/10.24885/sab.v26i2/1.384

FUNARI, Pedro Paulo A.; ROBRAHN-GONZÁLEZ, Erika M. Ética, capitalismo e arqueologia pública no Brasil. História, v. 27, n. 2, p. 13-30, 2008. Disponível em: http://repositorio.unicamp.br/handle/REPOSIP/1290.

FUNDAÇÃO ARAPORÃ (2015). Programa de Capacitação Técnica e Curadoria de Acervos Museu Histórico e Pedagógico "Voluntários da Pátria" (MHPVP). Relatório Final.

FUNDAÇÃO ARAPORÃ (2019). Programa de Capacitação Técnica e Curadoria de Acervos Musealizados. Relatório Final.

FUNDAÇÃO ARAPORÃ (2019). Programa de Gestão do Patrimônio Arqueológico. Salvamento Arqueológico, Prospecção e Educação Patrimonial na Área do Sítio Arqueológico Cemitério Maranata, Município de Olímpia, Estado de São Paulo. Relatório Parcial.

LAIA, Paulo Otávio. Percursos e Fronteiras: os labirintos entre proteção legal e a salvaguarda institucional das coleções arqueológicas no Brasil. Revista de Arqueologia Pública, v.11, n.2, p. 166-185. nov. 2017. Disponível em: https://periodicos.sbu.unicamp.br/ojs/index.php/rap/article/view/8650098/17174.

MANO, Marcel. Os Campos de Araraquara: Um estudo de história indígena no interior paulista. 2006. Tese (Doutorado em Ciências Sociais), Universidade Estadual de Campinas, Campinas, 2006. Disponível em: http://repositorio.unicamp.br/jspui/handle/REPOSIP/280084.

MARTINEZ, David Barreiro. Conocimiento y acción en la Arqueología Aplicada. Complutum, v. 17, p. 205-219, 2006.

MORAES WICHERS, Camila de Azevedo. Museus e Antropofagia do patrimônio arqueológico: (des)caminhos da prática brasileira. 2010. Tese (Doutorado em Museologia), Universidade Lusófona de Humanidades e Tecnologias, Lisboa-Portugal, 2010. Disponível em: http://www.museologia-portugal.net/files/upload/doutoramentos/ camila_moraes_parte1.pdf.

MORAES WICHERS, Camila de Azevedo. Patrimônio arqueológico paulista: proposições e provocações museológicas. 2011. Tese (Doutorado em Arqueologia), MAE/USP, São Paulo, 2011. Disponível em: https://repositorio.usp.br/item/002284692.

PLANO MUSEOLÓGICO. Museu de Arqueologia e Paleontologia de Araraquara. Araraquara, SP, jan. 2014.

PLANO MUSEOLÓGICO. Museu Histórico e Pedagógico "Voluntários da Pátria”. Araraquara, SP, dez. 2011.

POUGET, Frederic Mario Caires; CARVALHO, Aline Vieira. Arqueologia Pública e Acervo Arqueológico. Revista de Arqueologia Pública, v.11, n. 2, p. 254-263, nov. 2017. Disponível em: https://doi.org/10.20396/rap.v11i2.8651104.

RODRIGUES, Robson Antonio. Os caçadores ceramistas do sertão paulista: um estudo etnoarqueológico da ocupação kaingang no vale do rio Feio/Aguapeí. 2007. Tese (Doutorado 
em Arqueologia), MAE/USP, São Paulo, 2007. Disponível em: https://www.teses.usp.br/teses/disponiveis/71/71131/tde-12092007-141110/pt-br.php.

SCHIAVETTO, Solange Nunes de Oliveira. Arqueologia regional e educação: propostas de estudos sobre um "passado excluído" de Araraquara/SP. 2007. Tese (Doutorado em História Cultural), Universidade Estadual de Campinas, Campinas, 2007. Disponível em: http://repositorio.unicamp.br/handle/REPOSIP/280840.

SOUSA, João Carlos Moreno de. Tecnologia de ponta a ponta: em busca de mudanças culturais durante o holoceno em indústrias líticas do Sudeste e Sul do Brasil. Revista de Arqueologia. V. 32 N. 1.2019.

SOUZA, Laize Carvalho de. Arqueologia Pública e sua práxis social: uma contribuição necessária para a preservação de recursos arqueológicos e interação social. Cadernos do Lepaarq, v. XV, $\mathrm{n}$. 30, p. 80-97, jul-dez. 2018. Disponível em: https://periodicos.ufpel.edu.br/ojs2 /index.php/lepaarq/article/view/13214.

WICHERS, Camila Azevedo de Moraes. Dois enquadramentos, um mesmo problema: Os desafios da relação entre museus, sociedade e patrimônio arqueológico. Revista de Arqueologia, v. 26, n. 2/1, p. 16-39, 4 jul. 2014. Disponível em: https://doi.org/10.24885/sab.v26i2/1.380.

ZANETTINI, Paulo; MORAES WICHERS, Camila A. Arqueologia Preventiva e o Ensino de Arqueologia no Brasil. Revista Habitus, v. 12, n. 2, p. 239-256, jul./dez. 2014. Disponível em: http://seer.pucgoias.edu.br/index.php/habitus/article/view/4079/2330.

\section{Sites consultados}

Banco de dados Cadastro Nacional de Sítios Arqueológicos. Disponível em: http://portal.iphan.gov.br/sgpa/cnsa_resultado.php.

Sobre legislação referente à preservação e gestão do patrimônio arqueológico. Disponível em: http://portal.iphan.gov.br/legislacao. 